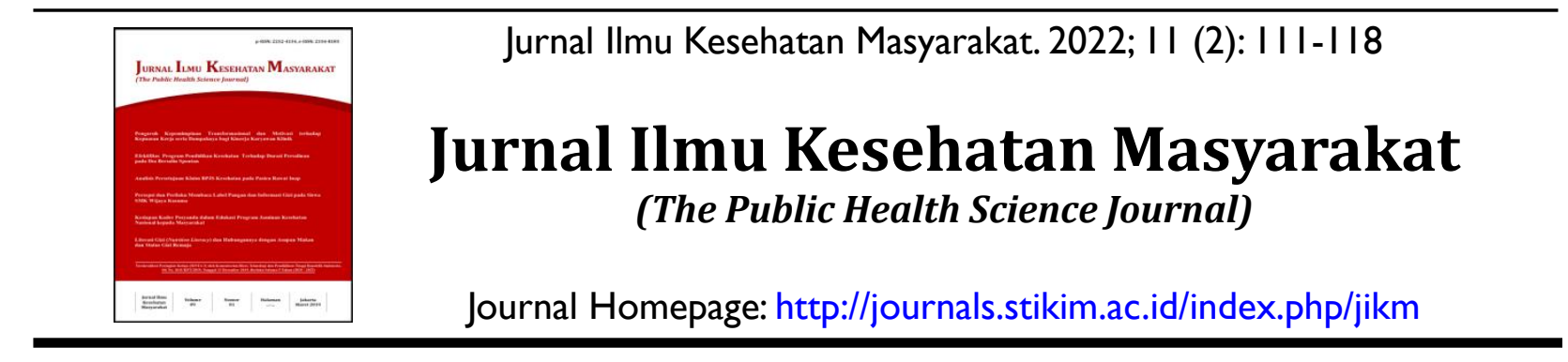

\title{
Systematic Review : Efektivitas Telemedicine pada Pelayanan Antenatal di Masa Pandemi COVID-19
}

\author{
Yundri Martiraz ${ }^{1}$, Adik Wibowo $^{2}$, Amelia Fauzia ${ }^{3}$ \\ ${ }^{1-3}$ Magister Kajian Administrasi Rumah Sakit, Fakultas Kesehatan Masyarakat, Universitas Indonesia
}

\begin{abstract}
Abstrak
Ibu hamil adalah salah satu kelompok yang rentan terinfeksi virus SARS COV-2. Telemedicine manjadi salah satu alternatif solusi yang dapat diimplementasikan bagi ibu hamil yang akan melakukan pemeriksaan antenatal selama masa pandemi berlangsung. Telemedicine dapat menghilangkan proses tatap muka antara wanita hamil dengan dokter, ataupun dengan lingkungan rumah sakit. Tujuan dari penulisan ini adalah untuk mengetahui efektivitas dari telemedicine bagi wanita hamil yang melakukan pemeriksaan antenatal. Systematic review adalah penelusuran artikel dengan metode Preferred Reporting Items for Systematic Reviews (PRISMA) dengan mengakses empat online database (Scopus, Proquest, Pubmed, dan Science Direct), dengan mengumpulkan data pada tahun 2020 sampai dengan tahun 202I. Setelahnya penulis melakukan ekstraksi data dan bias appraisal. Dengan total artikel yang ditemukan dan telah dipilih sebanyak enam artikel, yang terdiri dari tiga studi potong lintang, satu kohort, satu uji kontrol teracak, dan satu metode campuran. Mayoritas hasil dari keseluruhan studi ini dikatakan tidak hanya kepuasan pasien dengan menggunakan telemedicine bagi pasien maupun providers (tenaga kesehatan), tetapi efisiensi pada waktu dan biaya menjadi luaran tambahan yang baik. Kesimpulan dari studi ini adalah telemedicine sangat mampu memberikan keuntungan dan efektivitas yang baik dalam pelayanan antenatal selama masa pandemic COVID-I9.
\end{abstract}

Kata Kunci: COVID-19, efektivitas, pelayanan antenatal, telemedicine.

\begin{abstract}
Pregnant women are the most susceptible category for getting infected by SARS COV-2 virus. There is a solution that can give more convenience way for pregnant women to get antenatal care during pandemic, Telemedicine. Telemedicine can dismiss physical contact between pregnant women and doctor, and also with hospital surrounding. The purpose of this study is to know the outcome from Telemedicine for pregnant woman who doing antenatal care. This study is a systematic review method with PRISMA and used four online databases (Scopus, Proquest, Pubmed, and Science Direct) that collect data from 2020 until 202I. After that we extracted data and bias appraisal. The result has 3 cross sectional study, a cohort, a randomized control trial, and a mix method. Majority result from those study is not only satisfaction by using telemedicine in two arms (patient and provider), but also time and cost efficiency included as a positive outcome. The conclusion is telemedicine can give benefit and effectiveness of antenatal care during COVIDI 9 pandemic.
\end{abstract}

Keywords: COVID-19, effectiveness, antenatal care, telemedicine.

Korespondensi*: Yundri Martiraz, Magister Kajian Administrasi Rumah Sakit, Fakultas Kesehatan Masyarakat, Universitas Indonesia, Kampus Baru UI Depok Jawa Barat - I6424, Email:ymartiraz@gmail.com, No.Telp: +628I I 929376 


\section{Pendahuluan}

Pelayanan antenatal merupakan suatu pelayanan kesehatan pada ibu hamil dengan memberikan supervisi masa kehamilan secara regular dan periodik yang dimulai dari awal kehamilan sampai dengan persalinan. ${ }^{1}$ Hal ini dilakukan dalam upaya untuk membantu mengurangi angka kematian ibu dan keguguran, begitu pula dengan cacat pada kelahiran, berat badan lahir rendah (BBLR), infeksi neonatus dan masalah kesehatan lainnya yang dapat dicegah. Pelayanan antenatal harus dilakukan oleh tenaga profesional terlatih terhadap ibu hamil untuk memastikan kondisi kesehatan terbaik bagi ibu dan bayinya. ${ }^{2}$ Menurut data World Health Organization (WHO) pada tahun 2017 ada sekitar 810 wanita setiap harinya (295.000) yang mengalami kematian dikarenakan oleh penyebab yang berhubungan dengan kehamilan dan melahirkan. ${ }^{3}$ Ibu hamil yang mendapatkan pelayanan antenatal dengan tenaga profesional terlatih sudah terbukti akan menurunkan kejadian kematian neonatal sebesar 34\%-39\% di negara Afrika dibandingkan dengan ibu hamil yang tidak melakukan pemeriksaan antenatal. ${ }^{4,5}$

Di masa pandemi Corona Virus Desease (COVID-19) saat ini menyebabkan masyarakat khawatir untuk datang ke rumah sakit karena beranggapan akan tertular virus. Ibu hamil merupakan kelompok rentan tertular virus. Menurut suatu survei daring yang dilakukan di Amerika terhadap 4.451 ibu hamil, hampir sepertiganya merasa stres dengan kondisi yang terjadi saat ini, sehingga menyebabkan penurunan cakupan pelayanan antenatal karena ibu hamil melakukan penundaan untuk memeriksakan kehamilannya. ${ }^{6}$ Pada suatu survei yang dilakukan di Afrika, banyak suami dari ibu hamil melarang istrinya untuk datang ke fasilitas pelayanan keseshatan dengan kekhawatiran tentang virus yang akan menginfeksi dan ketidakpercayaan terhadap tenaga kesehatan dan juga responden wanita mengatakan bahwa mereka tidak mengakses pelayanan kesehatan karena takut dengan situasi pandemi saat ini dan kebingungan tentang pelayanan apa saja yang masih diselenggarakan. $^{7}$ Pada suatu penelitian cross-sectional yang dilakukan oleh Semaan et al., dengan melakukan survei online secara global, ditemukan adanya penurunan yang cukup signifikan dalam unit pelayanan antenatal yang disebabkan oleh berkurangnya jam operasional fasilitas pelayanan kesehatan, restriksi jumlah pengunjung dan kunjungan tatap muka selama kehamilan. ${ }^{8}$

Pengunaan layanan antenatal dengan menggunakan media teknologi atau yang biasa disebut dengan telemedicine menjadi salah satu cara yang direkomendasikan. WHO mendefinisikan telemedicine sebagai pemberian layanan perawatan kesehatan, di mana jarak merupakan faktor penting, oleh semua profesional perawatan kesehatan yang menggunakan teknologi informasi dan komunikasi untuk pertukaran informasi yang valid untuk diagnosis, pengobatan dan pencegahan penyakit dan cedera, penelitian dan evaluasi untuk pendidikan berkelanjutan bagi penyedia layanan kesehatan, semuanya untuk kepentingan memajukan kesehatan individu dan komunitas mereka. ${ }^{9}$

Telemedicine dapat diklasifikasikan menurut metode, waktu dan tujuan komunikasi dan individu yang terlibat dalam komunikasi. Cara komunikasi dapat melalui teks (Teks: Aplikasi telemedicine berbasis obrolan, layanan pesan singkat, platform obrolan seperti WhatsApp, Google Hangout, Facebook Messenger, Email, Faks) dan video maupun audio (telepon, aplikasi audio). Tujuan dari konsultasi melalui telemedicine dapat berupa konsultasi awal dimana pasien melakukan konsultasi untuk pertama kalinya atau pasien lama yang sudah tidak berkonsultasi selama lebih dari enam bulan juga pasien ingin mengkonsultasikan kasus atau keluhan yang berbeda. Tujuan lainnya adalah konsultasi lanjutan yang masih dalam rentang waktu selama enam bulan. ${ }^{10}$

The Australian Institute of Health and Welfare $(A I H W)$ mengatakan bahwa pelayanan antenatal di bulan Maret-September 2020 dilakukan secara 
telehealthdikarenakan diberlakukannya system lockdown di negaranya. Hal ini dianggap cara yang aman untuk mengurangi transmisi infeksi saat pandemi terjadi. Tetapi apakah telemedicine dalam pelayanan antenatal merupakan pilihan alternatif yang tepat sebagai cara untuk untuk mengurangi penyebaran dan resiko terinfeksi bagi ibu hamil. ${ }^{6}$ Oleh karena itu, tujuan penulisan ini adalah untuk mengetahui sejauh mana efektivitas dari telemedicine terhadap layanan antenatal pada ibu hamil dari segi biaya, waktu, dan kepuasan dalam menggunakan telemedicine.

\section{Metode}

Penelitian ini menggunakan alur Preferred Reporting Items for Systematic Reviews (PRISMA) dengan menghilangkan proses meta analisisnya. Dalam metode pencarian data, penelusuran jurnal berasal dari sistem database Scopus, Proquest, Pubmed, dan Science Direct yang dibatasi pada masa pandemi COVID-19 yaitu dari tahun 2020 sampai 2021, dengan kata kunci antenatal care, telemedicine or tele-health, and effectiveness. Peneliti menggunakan
Mendeley sebagai reference manager untuk memudahkan pengumpulan dan pengutipan dokumen yang telah dipilih.

Setelah jurnal dan artikel diperoleh kemudian langkah selanjutnya yang peneliti lakukan adalah menyaring berdasarkan judul dan abstrak, yang dipilih peneliti dengan kriteria sesuai yang diinginkan yaitu tentang efektifitas telemedicine pelayanan antenatal di masa pandemi COVID-19, sedangkan jurnal yang tidak relevan dikeluarkan. Jurnal dan artikel yang dipilih berdasarkan kriteria inklusi dan ekslusi. Penulis menentukan kriteria inklusi yaitu ibu hamil yang melakukan pelayanan antenatal, konsultasi telemedicine, dimasa pandemic COVID-19, full text journal, dan artikel berbahasa inggris. Sedangkan untuk kriteria eksklusi, penulis menentukan artikel yang tidak akan masuk kriteria adalah pasien umum, ibu hamil yang terinfeksi COVID-19, melakukan konsultasi tatap muka, dan artikel selain berbahasa inggris. Selain menetapkan kriteria inklusi dan eksklusi, penulis juga melakukan pencarian artikel yang sesuai dengan kaidah PICO pada Tabel 1 .

Tabel 1. Model PICO

P : Patient, Problems, Population
I : Intervention
C : Comparison
O : Outcome
S : Study

\section{Hasil Penelitian}

Analisis data dilakukan dengan kajian mendalam hasil akhir jurnal yang disaring berdasarkan PRISMA dan juga dilakukan critical appraisal menggunakan Joanna Bridge Institute (JBI) tools untuk menilai validitas dan relevansi jurnal yang terpilih. Gambar 1 merupakan alur dalam menyeleksi artikel studi berdasarkan alur systematic review.

Pencarian artikel dari 4 basis data online didapatkan 253 studi, setelah mengeluarkan studi yang sama atau duplikasi dari 4 basis data dilakukan penilaian dengan membaca abstrak dan menilai isi keseluruhan dari isi artikel didapat 6 studi yang termasuk dalam kriteria inklusi. Di dapatkan hasil 3 studi potong lintang, satu studi kohort, satu studi acak, dan satu studi metode campuran (mix method). Kami menarasikan keenam artikel yang didapat yang berdasarkan dengan kriteria inklusi dan eksklusi yang sebelumnya kami sebutkan. Keseluruhnya artikel penelitian ini dipilih untuk menjadi penguat jawaban dari tujuan penelitian. Peneliti mengkompilasikannya pada tabel 3, meliputi nama peneliti, tahun penelitian, judul artikel, tujuan penelitian, model penelitian, jumlah sampel penelitian, dan 
kesimpulan. Terdapat tiga artikel yang melibatkan informan dari sisi pasien sebagai pengguna layanan dan sisi provider sebagai penyelenggara layanan, hal ini memberikan gambaran yang lebih luas tentang layanan antenatal dengan menggunakan telemedicine. Sedangkan tiga sisanya hanya menggunakan pasien yang menggunakan layanan antenatal telemedicine. Dari keenam artikel yang didapat kesemuanya memberikan pengalaman yang memuaskan dan positif dalam melakukan antenatal telemedicine baik dari sisi pengguna maupun penyelenggara (provider). Penggunaan antenatal telemedicine ini dikatakan dapat memperluas akses pelayanan selama pandemi COVID-19. Sehingga keseluruhannya dapat menggambarkan tingginya tingkat keefektifan layanan antenatal telemedicine diera pandemi COVID-19.
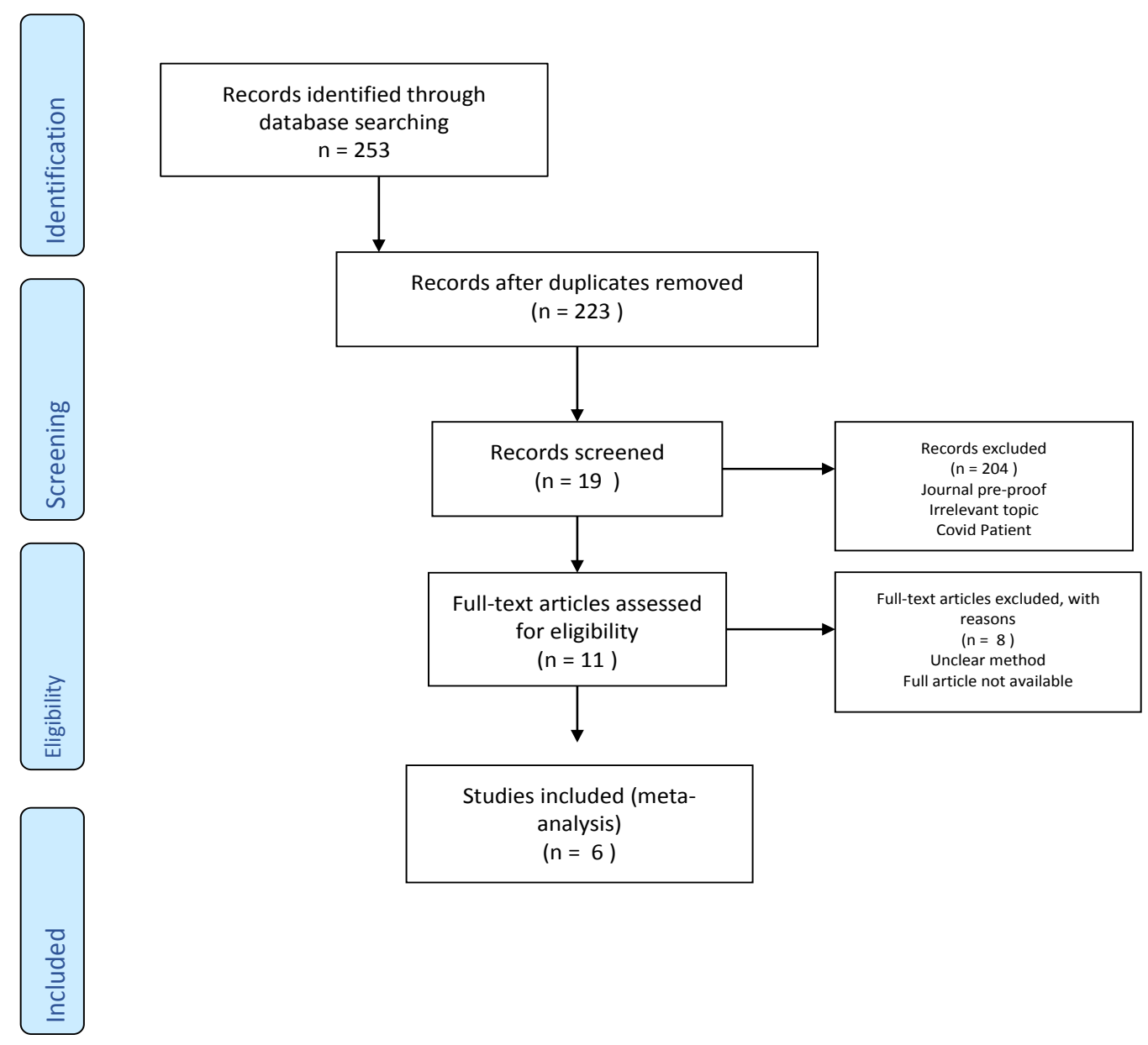

Gambar 1. Bagan Alur Seleksi Studi Berdasarkan Metode PRISMA 


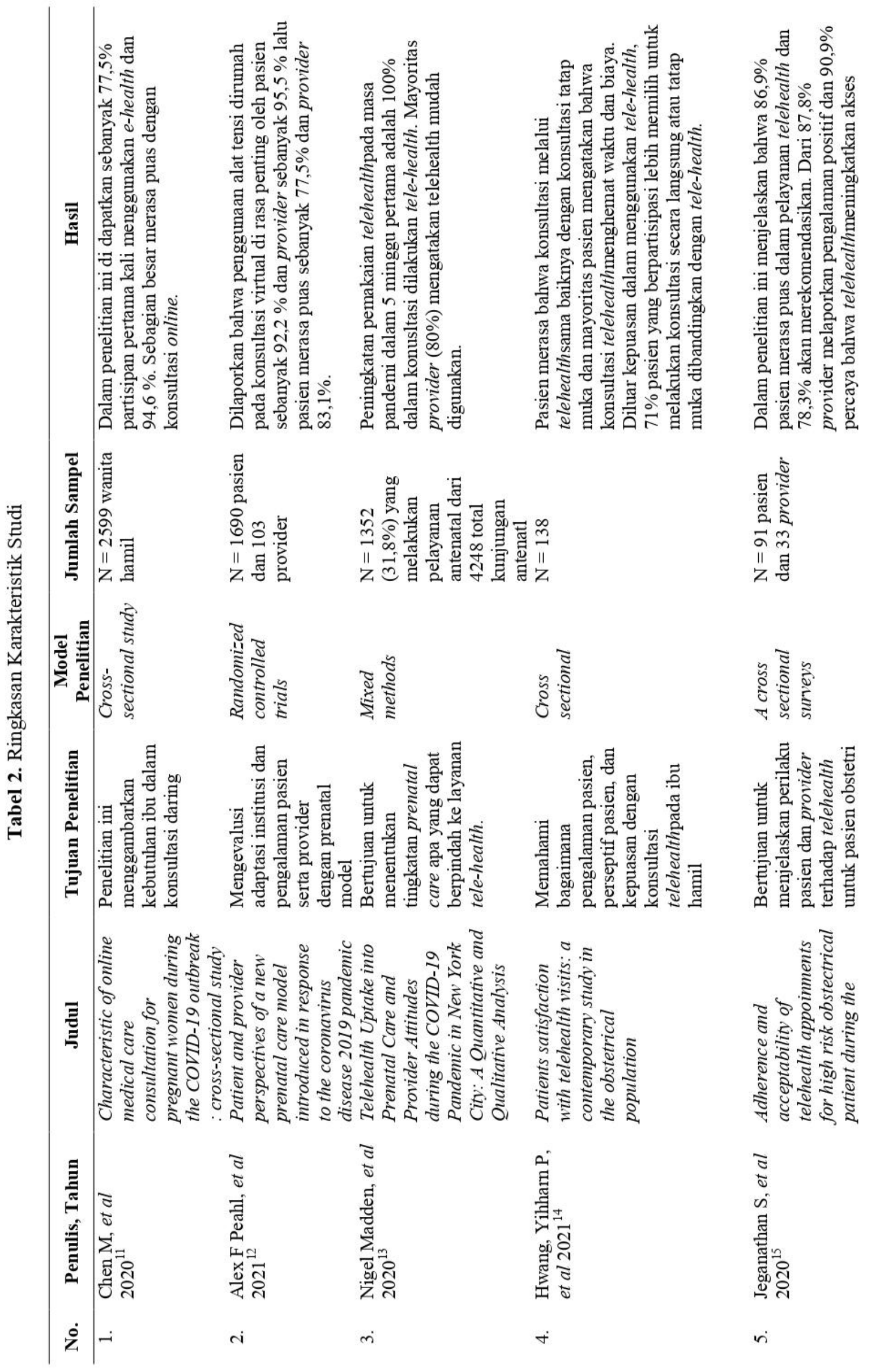




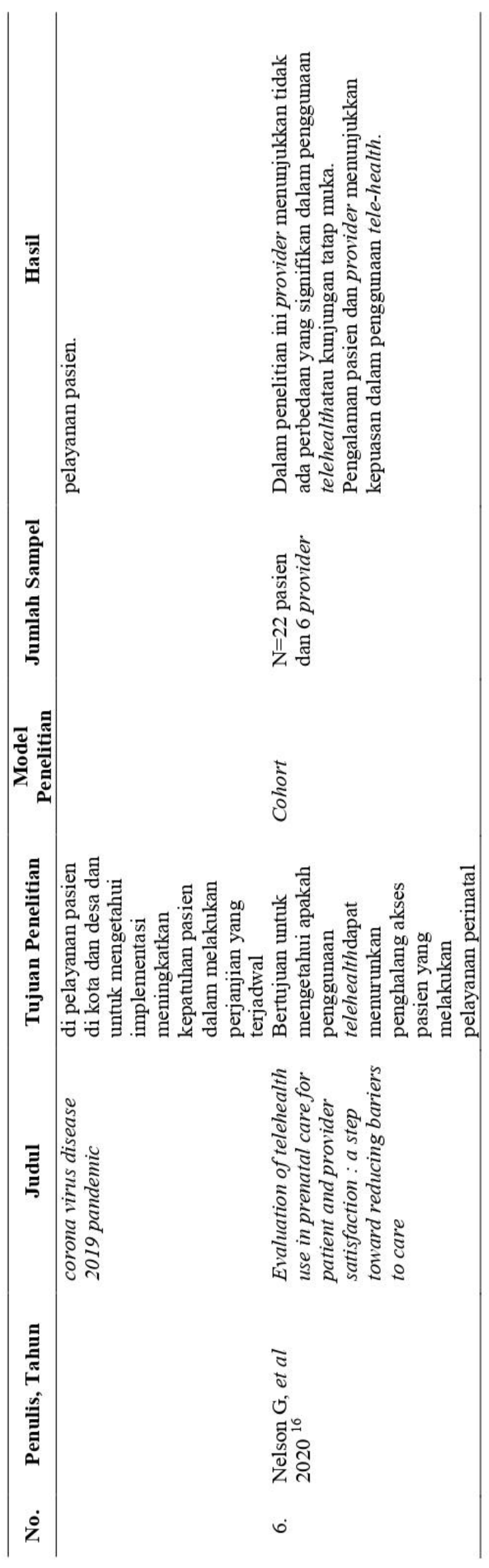

\section{Pembahasan}

Pada penelitian yang dilakukan Chen $\mathrm{M}$, et al hasil yang didapatkan bahwa sebelum pandemi ditemukan wanita hamil paling banyak melakukan konsultasi online adalah pada trimester pertama kehamilan, namun pada saat masa pandemi berlangsung didapatkan peningkatan penggunaan konsultasi online atau telemedicine adalah ibu hamil pada trimester kedua dan ketiga. Hal ini dipengaruhi oleh pembatasan wilayah yang dilakukan pemerintahan setempat karena kekhawatiran tertular dan untuk mengurangi penyebaran virus COVID-19. ${ }^{11}$ Hal ini juga telah disampaikan Central of Disease Control (CDC) tahun 2020 bahwa fasilitias telemedicine merupakan suatu strategi dalam mengurangi penularan virus di masa pandemi dengan penerapan social distancing. Tingkat kepuasan pasien diteliti berdasarkan daerah yang sesuai dengan jumlah kasus infeksi COVID-19, secara umum tingkat kepuasan pasien dalam melakukan konsultasi online cukup tinggi yaitu $90 \%$ di area ringan-sedang namun di area yang tingkat penuluran tinggi ternyata hasil yang didapatkan paling rendah. ${ }^{17}$

Hal ini sejalan dengan penelitian yang dilakukan Pheal AF et al., yang menjelaskan adanya peningkatkan konsultasi online sebanyak $136,6 \%$ dan memberikan pengalaman yang baik bagi ibu hamil maupun provider terutama dijelaskan bahwa telemedicine atau konsultasi online mudah digunakan dan kepuasan juga didapatkan karena aplikasi telemedicine yang tersedia mudah untuk diakses, meskipun pandemi usai pasien akan tetap melanjutkan konsultasi online, dimana hal ini juga sejalan dengan perspektif provider. ${ }^{12}$ Namun dalam penelitian ini juga diketahui bahwa dibutuhkan peningkatan dalam persiapan konsultasi online, kemudian yang menyebabkan kepuasan pasien rendah dalam konsultasi online ini adalah sulitnya membina hubungan antara pasien dan provider serta adanya kepercayaan di kalangan pasien bahwa konsultasi online tidak dapat menggantikan konsultasi tatap 
muka.

Penelitian lebih lanjut di sampaikan oleh Madden $\mathrm{N}$ et al., dalam studi yang dilakukan secara kuantitaf menunjukan angka signifikan pada peningkatan kunjungan konsultasi online melalui telemedicine, masing-masing pada dokter spesialis obstetri $(56,1 \%)$, subspesialis fetomaternal $(61,5 \%)$ dan klinik kesehatan (41,5\%). Kemudian hasil pada studi yang dilakukan secara kualitatif, pasien merasa aman karena tidak terpapar virus meskipun merasa sedikit kesulitan dalam menggunakan telemedicine dan perlu mempunyai alat pengukur tekanan darah sendiri. Provider mengatakan terdapat tiga kendala yang ditemui, yaitu komunikasi, kendala saat akan masuk kedalam aplikasi dan keterbatasan data. ${ }^{13}$ Hal ini sejalan dengan penelitian yang dilakukan di Amerika. Terdapat peningkatan penggunaan telemedicine sebesar $8729 \%$ dikarenakan biaya yang terjangkau, sehingga hal ini salah satu faktor yang memudahkan transisi dari cara tradisional secara tatap muka dengan menggunakan teknologi telemedicine. ${ }^{18}$

Penelitian lain juga dilakukan oleh Hwang YP et al., yang menunjukkan adanya hasil kepuasan pada responden yaitu pasien yang ikut dalam penelitian memperlihatkan respon yang tinggi karena dengan melakukan pemeriksaan prenatal melalui telehealthdikatakan dapat menghemat waktu dan biaya. Walaupun mereka tetap memiliki keinginan untuk bisa melakukan pelayanan prental secara tatap muka. ${ }^{14}$ Dalam penelitian yang dilakukan oleh Jeganathan menyebutkan bahwa kepatuhan pasien dalam perjanjian telehealthmenunjukan nilai yang tinggi, selain dikatakan bahwa dominasi pasien menunjukan kepuasan dan mengharapkan telehealthsebagai alternatif layanan kesehatan yang dapat menjangkau kemudahan akses bagi pasien. ${ }^{15}$ Sejalan dengan kesimpulan diatas, pada artikel yang ditulis oleh $\mathrm{Wu}$ menyatakan bahwa online antenatal sangat bermanfaat sebagai alternatif bagi ibu hamil yang memerlukan pelayanan dasar kehamilan dan juga konsultasi tentang kesehatan mental. Hal ini akan memberikan kontribusi dalam mengurangi morbiditas dan mortalitas maternal dengan memfasilitasi cakupan yang luas dengan keuntungan yang dirasakan oleh kedua pihak, baik penyedia pelayanan (providers) dan juga bagi ibu hamil baik dari segi biaya, waktu dan kemampuan. ${ }^{19}$

Hasil yang juga dikemukakan oleh Nelson GA et al., bahwa telehealth menunjukan fleksebilitas yang tinggi dalam menjalankan pelayanan prenatal. Dan pasien merasa memiliki kemampuan baru dalam melakukan pengukuran tekanan darah dan denyut jantung janin menggunakan Doppler. $^{16}$

\section{Kesimpulan}

Dari keseluruhan artikel yang didapat oleh penulis, bahwa pelayanan antenatal melalui telemedicine di masa pandemi COVID19 sangat efektif, dimana dari hasil yang didapat terlihat adanya peningkatan dalam penggunaan telemedicine dan kepuasan pasien dalam hal menghemat waktu dan biaya, juga ibu hamil tidak merasa khawatir tertular virus COVID-19 dalam perjalanan dan saat berada di Rumah Sakit. Namun terdapat satu penelitian dimana hasilnya menunjukan bahwa konsultasi tatap muka masih dianggap lebih efektif karena adanya keterikatan hubungan antara pasien dan dokter. Sehingga dapat disimpulkan bahwa telemedicine menjadi salah satu alternatif yang baik dalam pelayanan antenatal bagi ibu hamil dimasa pandemi COVID19. Pada penulisan ini lebih mengukur keuntungan dan kelebihan dengan melakukan pelayanan antenatal menggunakan telemedicine tetapi masih belum membahas tentang kendala dan kerugian yang dihadapi. Maka diharapkan penelitian selanjutnya akan membahasnya lebih kompresehnsif lagi dengan melihat dua sudut pandang dari keuntungan dan kerugian yang dihadapi.

\section{Daftar Pustaka}

1. Saranya G. E-Health Assistance for Antenatal Care. Res J Pharm Technol [Internet]. Agustus 2017;10(8):2561-3. Tersedia pada: 
https://search.proquest.com/scholarly-journals/ e-health-assistance-antenatal-care/docview/198 1604350 /se-2?accountid $=17242$

2. World Health Organization. WHO recommendations on antenatal care for a positive pregnancy experience. Geneva; 2016.

3. World Health Organization. Maternal Mortality. 2019.

4. Tekelab T, Chojenta C, Smith R LD. The impact of antenatal care on neonatal mortality in sub-Saharan Africa: A systematic review and meta-analysis. PLoS One. 2019;14 (9)(e0222566).

5. Wondemagegn AT, Alebel A, Tesema C, Abie W. The effect of antenatal care follow-up on neonatal health outcomes: a systematic review and meta-analysis. Public Health Rev [Internet]. 2018;39(1):33. Tersedia pada: https://doi.org/10.1186/s40985-018-0110-y

6. Australian Institute of Health and Welfare. New report looks at uptake of telehealth in antenatal care during COVID-19 lockdown. 2021.

7. ReliefWeb. Rapid Gender Analysis COVID-19 : West Africa - April 2020 - Benin. 2020.

8. Semaan AT, Audet C, Huysmans E, Afolabi BB, Assarag B, Banke-Thomas A, Blencowe H, Caluwaerts S, Campbell OM, Cavallaro FL CL. Voices from the frontline: findings from a thematic analysis of a rapid online global survey of maternal and newborn health professionals facing the COVID-19 pandemic. BMJ Glob Heal. 2020;5(6):e0029.

9. World Health Organization. Telemedicine : Opportunities and Developments in Member State. Geneva: WHO Press; 2010.

10. Board of Governors Medical Council of India. Telemedicine Practice Guidelines. India; 2020.

11. Chen M, Liu X, Zhang J, Sun G, Gao Y, Shi Y, et al. Characteristics of online medical care consultation for pregnant women during the COVID-19 outbreak: cross-sectional study. BMJ Open [Internet]. 2020;10(11). Tersedia pada:

https://search.proquest.com/scholarly-journals/ characteristics-online-medical-care-consultatio n/docview/2461171528/se-2? accountid $=17242$

12. Peahl AF, Powell A, Berlin H, Smith RD, Krans E, Waljee J, et al. Patient and provider perspectives of a new prenatal care model introduced in response to the coronavirus disease 2019 pandemic. Am J Obstet Gynecol [Internet]. 2021;224(4):384.e1-384.e11. Tersedia

pada: https://www.sciencedirect.com/science/article/p ii/S0002937820311807

13. Madden N, Emeruwa UN, Friedman AM, Aubey JJ, Aziz A, Baptiste CD, et al. Telehealth Uptake into Prenatal Care and Provider Attitudes during the COVID-19 Pandemic in New York City: A Quantitative and Qualitative Analysis. Am J Perinatol [Internet]. 2020/06/09. Agustus 2020;37(10):1005-14. Tersedia pada: https://pubmed.ncbi.nlm.nih.gov/32516816

14. Hwang YP, Kothmann MM, Berry MJ, Saade GR, Saad AF. 1064 Patient satisfaction with telehealth visits: a contemporary study in the obstetrical population. Am J Obstet Gynecol [Internet]. 2021;224(2, Supplement):S658. Tersedia pada: https://www.sciencedirect.com/science/article/p ii/S0002937820324650

15. Jeganathan S, Prasannan L, Blitz MJ, Vohra N, Rochelson B, Meirowitz N. Adherence and acceptability of telehealth appointments for high-risk obstetrical patients during the coronavirus disease 2019 pandemic. Am J Obstet Gynecol MFM [Internet]. 2020;2(4, Supplement):100233. Tersedia pada: https://www.sciencedirect.com/science/article/p ii/S2589933320302019

16. Nelson GA, Holschuh C. Evaluation of Telehealth Use in Prenatal Care for Patient and Provider Satisfaction: A Step Toward Reducing Barriers to Care. J Nurse Pract [Internet]. 2021; Tersedia pada: https://www.sciencedirect.com/science/article/p ii/S1555415520307224

17. CDC. Using Telehealth to Expand Access to Essential Health Services During the COVID-19 Pandemic [Internet]. CDC Website. 2019 [dikutip 16 Juni 2021]. Tersedia pada: https:/www.cdc.gov/coronavirus/2019-ncov/hc p/telehealth.html

18. Ramaswamy A, Yu M, Drangsholt S, Ng E, Culligan PJ, Schlegel PN, et al. Patient Satisfaction With Telemedicine During the COVID-19 Pandemic: Retrospective Cohort Study. J Med Internet Res [Internet]. 2020;22(9):e20786. Tersedia pada: http://www.jmir.org/2020/9/e20786/

19. Huailiang, Wu. Weiwei, Sun. Xinyu, Huang. Shinning, Yu. Hao, Wang. Xiaoyu, Bi. Jie, Sheng. Sihan, Chen. Babatunde, Akinwunmi. Casper, J P Zhang. Wai-Kit M. Online Antenatal Care During the COVID-19 Pandemic: Opportunities and Challenges. J Med Internet Reasearch. 2020;22(7): e19. 